\title{
Justified in their Actions: A Historiographic Analysis of the Causes of the Spithead and Nore Mutinies of 1797
}

\author{
ANDREW JOHNSTON
}

Abstract: Justified in their Actions takes an in-depth look at nearly two centuries of literature surrounding the Spithead and Nore Mutinies of 1797, one of the largest examples of collective action ever undertaken by any western military force. Despite arising from largely similar sources, the mutinies' end could not have been more different-that of the Channel Fleet at Spithead resulted in the Royal Navy's first pay raise in a century by Act of Parliament and a general pardon for all involved. The mutiny at the Nore, however, culminated in dozens of courts martial and over thirty hangings. In Justified in their Actions, the mutinies will be studied through the lens of the age-old debate of "sedition or ships' biscuits, "as it becomes clear that over-analysis of a subject can be just as dangerous as not studying it at all.

"Black, bloody mutiny" was among the most feared crimes in the Royal Navy of the eighteenth and nineteenth centuries. The 1749 Articles of War, the code of law which governed the sailing navy, clearly promised death for any "endeavour to make...mutinous assembly," mutiny was one of a select few crimes for which a court-martial would actually carry out that promise. ${ }^{1}$ The average sailor of the Royal Navy would have had ample reason to avoid engaging in such action, yet the British navy suffered several dozen cases of mutiny in the 1790 s alone. ${ }^{2}$ The question then arises: why did such action take place? What factors could have led to the breakdown of the famous ironclad discipline of the Royal Navy, and caused so many ships to rise up in rebellion? This question has been central to the arguments of virtually every writer on the subject for the past two hundred years, especially in regard to the "Great Mutinies" of Spithead and the Nore. These mutinies, which saw nearly a quarter of the fighting strength of the Royal Navy rise in rebellion between April and June 1797, remain unique among the history of the sailing navy due to their scale as well as their outcome: Spithead was resolved without a shot

\footnotetext{
${ }^{1}$ Consolidation Act, 22 Geo. II c. 33, Article 19.

${ }^{2}$ Niklas Frykman, "The Mutiny on the Hermione: Warfare, Revolution, and Treason in the Royal Navy," Journal of Social History 44, no. 1 (2010): 160.
} 
The Graduate History Review 9, no. 1 (2020)

being fired, whereas the Nore saw dozens of courts martial and nearly thirty mutineers hanged. ${ }^{3}$

The causes of the Spithead and Nore mutinies remain central to writings on the topic, but one must be careful when approaching such an expansive historiography. In The Face of Battle (1976), John Keegan laments "military historians' habitual reluctance to call a spade a spade."4 Other scholars have cautioned against the use of "conspiracy theories" to explain historical phenomena, as John Langbein argued regarding Douglas Hay's Property, Authority and the Criminal Law (1975). ${ }^{5}$ Although such an approach is not always completely fair to the complexities historians must face in their work, it is also important to not let such complexities completely eclipse the realities of the period. In the case of the Spithead and Nore mutinies, it is important that the grievances of the seamen remain central to the discussion of their outbreak, even as new analyses provide further understanding of the events. The question, then, is how does one approach the causes of these major mutinies? Discussion of the causes of the Spithead and Nore insurrections has varied over the past 200 years, but despite the specific factors which authors analyze, two major lines of thought have developed. The question, as described by Anthony Brown, is one of "sedition or ships' biscuits." 6 In other words, was mutiny caused by active revolutionary desire among a part or the whole of the crews, or a desire to have the Admiralty redress the grievances of the seamen, such as issues of pay, leave, food, and others that existed at the turn of the nineteenth century. Many authors have used some combination of the two to argue their perceived causes of the mutinies, but as will be shown it was the question of grievances that earlier writers chose to focus on more heavily, and that the majority of recent scholars have analyzed as well. Although there is still room for the discussion of revolutionary ideals within such an expansive historiography, many scholars have acknowledged that the "participation of Jacobins...is still conjectural"7 and "the evidence is still inadequate"8 to suggest any political motivations on behalf of the mutineers. Studying

${ }^{3}$ James Dugan, The Great Mutiny (London: The Trinity Press, 1965), 359.

${ }^{4}$ John Keegan, The Face of Battle (Jonathan Cape, 1976), 32.

${ }^{5}$ See John Langbein, "Albion's Fatal Flaws," Past and Present no. 98 (Feb. 1983): 96120.

${ }^{6}$ Anthony Brown, "The Nore Mutiny - Sedition or Ships' Biscuits? A Reappraisal" The Mariner's Mirror 91 no. 1 (2006): 60-74.

${ }^{7}$ Dugan, The Great Mutiny, 473.

${ }^{8}$ Andrew Lambert, review of The Naval Mutinies of 1797: Unity and Perseverance ed. by Ann Coats and Philip MacDougall, Annual Bulletin of Historical Literature 96 no. 1 (2013): 89-90. 
how historians have approached this question over the past two centuries, this paper is organized chronologically, attending individually to each major piece written on the subject of the "Great Mutinies." Beginning with the work of William Johnson Neale's work in the mid-nineteenth century and moving all the way to the recently published works of sociologists Michael Hechter, Steven Pfaff, and Katie Corcoran, I argue that the issue of grievances is the single strongest cause of mutiny in 1797.

One of the most widely-cited early histories of the Great Mutinies of 1797 was that published by William Johnson (sometimes spelt "Johnstoune") Neale in 1842. The son of a military physician and author, Neale was a former naval officer, author, and barrister, who coincidently was married to Frances Herbert, the eldest grandchild of Viscountess "Fanny" Nelson. ${ }^{9}$ His History of the Mutiny of Spithead and the Nore was published at the height of his career and was done so anonymously. Neale's name appeared nowhere in the original text, possibly signifying that his "suggestions for the prevention of future discontent in the Royal Navy" were somewhat controversial for their time. From a historical point of view, Neale's work is primarily a narrative account of the events of the Spithead and Nore mutinies of 1797, as well as their immediate causes and aftermath. However, in his efforts to explain the causes of the mutinies, Neale effectively summarized the two major historiographical strands that would dominate the discussion for the next two centuries; the aforementioned question of "sedition or ships' biscuits."

Neale, unlike later authors of the subject, chose not to argue the role of political conspiracies in the outbreak of the mutinies of 1797. However, he did acknowledge the fears that such collective action aroused at the time, especially in parliament, and emphasized that some form of shared impulse among the crews had a role in causing the mutiny, even if it did not come with the cry of liberté, égalité, fraternité. Neale noted that a desire for reform in the navy did not necessarily translate to a concrete desire for social revolution, and although he argued that the ringleaders should have been charged with treason rather than mutiny, this was due to Neale's belief in the "absurdity and injustice of courts martial" rather than a deep-seated belief that the mutineers were revolutionaries. ${ }^{10}$

Neale cited "grievances" as the main cause of the 1797 mutinies. Whether looking at "the shameful nature of the provision of the navy" or

\footnotetext{
${ }^{9}$ Gordon Goodwin, "Neale, William Johnstoune Nelson (1812-1893), lawyer and novelist," Oxford Dictionary of National Biography, accessed 20 March 2019: https://doi.org/10.1093/ref:odnb/19833.

${ }^{10}$ William Johnson Neale, History of the Mutiny at Spithead and the Nore (London: Bradburn and Evans, 1842), xii.
} 
The Graduate History Review 9, no. 1 (2020)

other specific factors, he recognized that there were many aspects of life in the Royal Navy of 1797 that the sailors took issue with. Importantly, he also emphasized a number of issues with the navy's code of discipline and brutal system of corporal punishment. ${ }^{11}$ Although such discipline definitely qualified as a grievance by most definitions of the term, it is unlikely that the seamen at Spithead and the Nore saw this in the same category as the everyday effect of corrupt pursers and the like, and this was very much the product of Neale's horror at the state of courts martial compared to common-law trials. ${ }^{12}$ Despite his heavy bias and a number of factual errors, his arguments for the various potential causes of the mutinies remain among the most important, lasting legacies of his work.

This became increasingly clear in the early twentieth century, when historians began to take a closer look at the 1797 mutinies and naval law in general. Conrad Gill's The Naval Mutinies of 1797 (1913) was very much the spiritual successor of Neale's book, although Gill specifically decried the former work as having "very little historical value... resolving itself into an attack on Pitt and his colleagues." ${ }^{13}$ Gill's volume would go on to become the standard historical analysis of the mutinies for the next several decades, and despite explicitly challenging Neale's factual accuracy, would be instrumental in propagating Neale's two causal theories of the mutinies for future historians. It is important to recognize that although Gill dedicated an entire book of his multi-volume work to the discussion of "the grievances of the seamen," he put a much greater emphasis on the socio-political factors of the outbreak than Neale did, explicitly arguing the revolutionary nature of the mutinies at Spithead, the Nore, and elsewhere. ${ }^{14}$

A self-proclaimed amateur in naval affairs, Gill argued that the social, political, and economic effects of the mutinies were their greatest legacy and therefore, the reason for his study. ${ }^{15}$ His discussion of the grievances of the mutineers followed along similar lines, as he categorized grievances into issues of wages and provisions, discipline, and "other grievances" which included impressment, prize money, and the corresponding lack of reform. ${ }^{16}$ Additionally, Gill conducted a comparative analysis of such grievances in 1797 and those of earlier centuries, tracing developments in wages and discipline back to the

\footnotetext{
${ }^{11}$ Neale, History of the Mutiny at Spithead and the Nore, 1.

${ }^{12}$ Neale, History of the Mutiny at Spithead and the Nore, 310.

${ }^{13}$ Conrad Gill, The Naval Mutinies of 1797 (University of Manchester Press, 1913), 395.

${ }^{14}$ Gill, The Naval Mutinies of 1797, 299.

${ }^{15}$ Gill, The Naval Mutinies of 1797, viii.

${ }^{16}$ Gill, The Naval Mutinies of 1797, xviii.
} 
sixteenth century. Despite the evident grievances of the seamen at Spithead and the Nore, Gill argued that these alone could only have led to mutiny if a significant change in the grievances had occurred immediately beforehand. Issues with pay, provisions, and discipline were longstanding in the Royal Navy, and barring any outside influence, such widespread unrest in 1797 should have not occurred. As stated, "the mutineers themselves appreciated the fact that there was nothing new in the hardship of which they complained," and Gill clearly attributed the "spark" to the democratic revolutionary fervour that was sweeping the Atlantic world during the late eighteenth century. ${ }^{17}$

Gill's central argument, and the manner by which he linked the grievances of the mutineers to the discussion of the political causes of the mutiny, was that the mutineers of 1797 were confronted with the idea that "the hardships they had endured were not essential to life in the navy."18 The theory of natural rights, which had spread along with democratic ideals around Europe, had finally arrived in the Royal Navy, and Gill clearly believed that it was this theory that provided the framework by which the sailors at Spithead and the Nore could have challenged such long-lasting grievances. ${ }^{19}$ At least one copy of Thomas Paine's Rights of Man was found aboard one of the mutinous ships, and Gill cited many clear examples of revolutionary rhetoric from the sailors, including their letters, petitions, and songs. ${ }^{20}$ It was these ideas, Gill argued, that convinced the mutineers that they need not deal with the status quo for any longer. Gill argued for the importance that this type of language played in the mutinies while clearly dispelling the myth that the revolutionary powers of Europe had taken any steps to instigate the mutinies. Despite this, the idea that these powers had played an active role in the mutinies' outbreak gained some traction in later years.

Conrad Gill's book formed the first account of the 1797 mutinies by a historian but was followed less than a year later by an equally groundbreaking work in the field of naval law-David Hannay's Naval Courts Martial (1914). This book, which remains the only published general history of British naval courts, does not focus on the 1797 mutinies to the

\footnotetext{
${ }^{17}$ Gill, The Naval Mutinies of 1797, 295.

${ }^{18}$ Gill, The Naval Mutinies of 1797, 299.

${ }^{19}$ The revolutionary ideals which swept Europe in the late-eighteenth century are often believed to have been "imported" to France following the American Revolution a decade earlier. For an English perspective, see Roy Porter's English Society in the Eighteenth Century, chapter 7. For primary materials, see Paine's Rights of Man, or Emmanuel Joseph Sieyès' What is the Third Estate?

${ }^{20}$ Gill, The Naval Mutinies of 1797, xi.
} 
The Graduate History Review 9, no. 1 (2020)

same degree as Neale or Gill, but is still notable as the first analytical work composed by a naval historian. Dealing with mutiny as a part of a larger whole, Naval Courts Martial analyzed the manner by which the courtmartial process actually functioned, thereby implicitly asking the questions "what causes crime" and "how did the Royal Navy dealt with it." Hannay defined the vague nature of mutiny as it existed in the navy at the time, notably equating mutinies of various sizes; the mariner who "was exasperated into threatening to throw [the boatswain] overboard was guilty of no less than mutiny," whereas "the crews of the fleet at Spithead, who combined to coerce the government" were guilty of no more. ${ }^{21}$ That said, he separated mutiny into two major categories - questions of discipline and of sedition. As suggested, the former was rarely violent and usually involved a single person or a small group at most. The latter, Hannay argued, was what broke out at the Nore in 1797, and the causes were larger than a simple breakdown in discipline. Hannay cited the cause of the mutiny at Spithead as "the acute manifestation of a chronic and absolutely just discontent with the way, and the times, in, and at which, the sailors were paid."22 While this is admittedly a much simpler understanding of the mutiny than was argued by either Neale or Gill, the focus on a specific grievance was equally as important to the understanding of the mutinies in years to come.

The works of Neale, Gill, and Hannay provided a suitable beginning to historical analysis of the mutinies of 1797, but it was quickly determined that such studies were incomplete. Neale's work was full of factual errors, and although Gill attempted to provide a much more comprehensive look into the historical context of the mutinies, he achieved only limited success due to his self-proclaimed status as an amateur naval historian. The lack of a formal historical narrative surrounding the events of 1797 inspired the next major work on the mutinies: George Manwaring and Bonamy Dobrée's The Floating Republic, originally published in 1935. According to the authors, the inspiration behind this book was a desire to approach the study of the mutinies from a different angle, using documents not available nor utilized by Gill. Also, they argue that Gill "seems to have had less sympathy with the sailors than we have," which is evident when looking at Manwaring and Dobrée's conclusion and perceived justification of the mutinies. ${ }^{23}$ Few

${ }^{21}$ David Hannay, Naval Courts Martial (University of Cambridge Press, 1914), 115.

${ }^{22}$ Hannay, Naval Courts Martial, 116.

${ }^{23}$ George Manwaring and Bonamy Dobrée, The Floating Republic (London: Geoffrey Bles, 1935), viii. 
scholars mentioned here or elsewhere suggest the mutiny at Spithead was not justified, as a resolution for the grievances endured by the seamen was long overdue. Combined with the incredible discipline and restraint displayed by the Spithead mutineers, few were unwilling to acknowledge their demands. On the other hand, the "very evil developments" that the Nore mutiny displayed made both contemporaries and later scholars significantly less comfortable sympathizing with them to the same degree as at those Spithead. ${ }^{24}$ And it is here that Manwaring and Dobrée differ from previous writers.

Manwaring and Dobrée chose to describe the first of the two 1797 mutinies as "the breeze at Spithead," emphasizing the extremely calm nature by which the entire affair was managed. ${ }^{25}$ Although they were not as gentle in their treatment of the Nore mutiny, their usage of Frederick Marryat's description clearly stated their opinion of the matter:

There is a point at which endurance of oppression ceases to be a virtue, and rebellion can no longer be considered as a crime: but it is a dangerous and intricate problem, be acknowledged, that the seamen, on the occasion of the first mutiny [Spithead], had just grounds of complaint, and that they [those at the Nore] did not proceed to acts of violence until repeated and humble remonstrance had been made in vain. ${ }^{26}$

In this capacity, Manwaring and Dobrée were among the first published historians who were substantially sympathetic to the Nore mutineers, and it is quite clear that this approach shaped their view of the causes of the mutinies. They argue that the grievances of the seamen were not with the Articles of War themselves, but rather illegal infractions against the Articles as stated in the Regulations and Instructions relating to Service at Sea, which was in its thirteenth edition by 1797. Manwaring and Dobrée argued that these infractions were noticed by many officers at the time, and it was well known that "every captain [had] taken upon him to establish rules for himself." ${ }^{27}$ Combined with the Admiralty's wilful denial of "a picture of culpable misadministration from top to bottom" in the Royal Navy, it was this knowledge that convinced many at the time,

\footnotetext{
${ }^{24}$ Gill, The Naval Mutinies of 1797, xi.

${ }^{25}$ Manwaring and Dobrée, The Floating Republic, 1.

${ }^{26}$ Manwaring and Dobrée, The Floating Republic, 245.

${ }^{27}$ Manwaring and Dobrée, The Floating Republic, 247.
} 
especially politicians, that external revolutionary pressures must have been the root cause of the mutinies. ${ }^{28}$

Manwaring and Dobrée did not argue against the possibility that revolutionary ideas swept the seamen at Spithead and the Nore, but they drew issue with the suggestion that such sentiments were intentionally spread through the work of Britain's enemies. The ideas of liberté, égalité, and fraternité were undoubtably present in the fleets and in the writings of domestic British thinkers such as Thomas Paine. However, Manwaring and Dobrée clearly put the suggestion of foreign involvement to rest with the simple answer that none of Britain's enemies made any effort to capitalize on the affair. Specifically, they mentioned the lack of response from the United Irishmen under Wolfe Tone, for whom the crippling of the majority of Britain's home fleet would have presented a golden opportunity to acquire French support for a strike against Britain. ${ }^{29}$ Additionally, knowledge of the mutiny would certainly have spelled doom for Admiral Duncan's deception of the Dutch fleet at Texel; had the Batavian Republic known that nearly the entirety of the North Sea Squadron was involved in the mutiny at the Nore, an earlier breakout of the besieged Dutch fleet would almost definitely have ensued. ${ }^{30}$ The success of Duncan's blockade and subsequent decisive victory at Camperdown in October 1797 suggests that knowledge of the mutinies was successfully kept from the French, Dutch and others, at least until well after the moment of opportunity had passed.

Whereas Manwaring and Dobrée chose, like their predecessors, to focus largely on the mutinies themselves, the next major work on the 1797 mutinies explicitly chose to analyze the wider world of contemporary insurrection, expanding even beyond the Royal Navy. In The Great Mutiny (1965), James Dugan studied the mutinies within the wider context of the French Revolution, the Irish rebellions, and the tide of "repression and reform" that swept Britain at the turn of the nineteenth century. ${ }^{31}$ In addition to this wider focus Dugan was also fortunate to possess a much more developed collection of secondary works surrounding the mutinies, which allowed a significantly larger discussion regarding problematic

\footnotetext{
${ }^{28}$ Manwaring and Dobrée, The Floating Republic, 247.

${ }^{29}$ Manwaring and Dobrée, The Floating Republic, 101.

${ }^{30}$ Manwaring and Dobree, The Floating Republic, 277. With the vast majority of his fleet in rebellion at the Nore, Admiral Duncan used the few ships available to him in an elaborate deception: his frigates stood just offshore, and his flagship several miles further out. By continuously passing signals between his ships, Duncan successfully convinced the Dutch that an entire British squadron was waiting just over the horizon.

${ }^{31}$ Dugan, The Great Mutiny, 34.
} 
approaches to them - approaches that further complicated the question of "sedition or ships' biscuits."

Dugan focused on two major causes for the outbreak of mutiny in 1797: grievances and "revolutionary fervour." His emphasis was much more on the former, but unlike Manwaring and Dobrée he greatly emphasized the importance that revolutionary sentiment played at Spithead and the Nore. Additionally, Dugan presented the narrative of the mutinies as a story, using first-person language and the present tense to convey a more "personal" version of the mutinies. ${ }^{32}$ Unfortunately, while this provided an intriguing "bottom-up" approach to the mutinies and their causes, it is harder to detect the structural causes that are more evident from a "top-down" study. Still, Dugan's comprehensive snapshot into the life of an eighteenth-century sailor that Dugan provided allowed for a different analysis of these grievances. His discussion regarding food, disease and general living conditions in the Royal Navy provides crucial context for understanding the grievances mentioned by other authors, notably without the pejorative language such authors are often wont to use. ${ }^{33}$ Dugan also chose to focus on the inequalities of prize money (rather than wages) in the navy to a greater degree than other authors, specifically regarding the battle of Camperdown shortly after the Nore. The difficulties that many had in obtaining their prize money clearly displayed that nothing had changed for the average sailor, or even Admiral Duncan. In effect, this further emphasized the desire of the Admiralty to ignore what was clearly a root cause of the mutinies in order to focus on external factors.

In addition to his focus on the grievances of the sailors, Dugan also analyzed the revolutionary aspects of the mutinies. Despite beginning his book with a discussion of the storming of the Bastille, Dugan was careful to avoid drawing a direct link between the two events. Both the 1797 mutinies and the French Revolution may have been influenced through similar political and social theories, but he suggested any theory directly linking one to the other is flawed. As Dugan and previous authors noted, the lack of reaction by the continental revolutionary governments suggested their lack of awareness of the 1797 fleet mutinies, and therefore the absence of any intent on their part behind the mutinies' outbreak. This was especially clear in his analysis of the battle of Camperdown, which

\footnotetext{
${ }^{32}$ Dugan, The Great Mutiny, 7.

${ }^{33}$ Neale, 5; Manwaring and Dobrée, 46.
} 
again argued that Duncan's success could only have come from FrancoDutch ignorance. ${ }^{34}$

Dugan also chose to emphasize the question of Irish loyalty, a point that future historians would return to. At the turn of the nineteenth century the Irish were the largest ethnic minority in the Royal Navyand with that group's history of insurrection against the British crown it was no surprise that a significant portion of Dugan's contemporaries, along with many historians, cited the Irish role in the mutinies' outbreak. However, as Dugan clearly stated, this was simply not true. Fear of French-supported Irish rebellion during the Revolutionary Wars was definitely wellfounded, as significant military pressure had been placed upon the British by groups such as Wolfe Tone's United Irishmen. Nevertheless, Dugan argued that although Irish rebels were planning to seize British warships as part of their insurrection, it was not until after the Spithead and Nore mutinies that they realized "the surprising effectiveness" of formulating sedition within the Royal Navy. ${ }^{35}$ The oath sworn by the mutinous members of the crew of the Defiance shows that members of this "Gaelic sea network" were hard at work as early as 1798 :

I swear to be true to the Free and United Irishmen, who are now fighting our cause against tyrants and oppressors, and to defend their rights to the last drop of my blood, and to keep all secret; and I do agree to carry the ship into Breast the next time the ship looks out ahead at sea, and to kill every officer and man that shall hinder us, except the master; and to hoist a green ensign with a harp on it; and afterwards to kill and destroy the Protestants. ${ }^{36}$

In contrast to other arguments Dugan kes it quite clear that although fears of Irish rebellion were well-justified in the discussion of naval mutiny, such large-scale insurrection only occurred after the Great Mutinies of Spithead and the Nore.

James Dugan's The Great Mutiny (1965) was, and remains, one of the most influential works on the Spithead and Nore mutinies because it was one of the first to have a developed historiography to draw upon. This was crucial, in fact, because Dugan dedicated the entire first appendix of his book to discussing one of the more radical arguments that had arisen surrounding the mutinies, that of E.P. Thompson in The Making of the

\footnotetext{
${ }^{34}$ Dugan, The Great Mutiny, 398-419.

${ }^{35}$ Dugan, The Great Mutiny, 427.

${ }^{36}$ Dugan, The Great Mutiny, 428.
} 
English Working Class (1963). ${ }^{37}$ It should be emphasized that the only naval connection in Thompson's book is a tangential reference to the plight of dockworkers, and that the mutinies are only mentioned in passing twice in the thousand-page book. ${ }^{38}$ Thompson's major assumption surrounding the 1797 mutinies, that of Jacobin and Irish ties to their outbreak, was one that Dugan explicitly rebutted in his own work. Like many previous scholars Dugan allowed for some revolutionary sentiment in his reasons for the mutinies' outbreaks, but as he himself argued, "the participation of Jacobins[in] the mutinies is still conjectural." ${ }^{13}$ Even allowing for some committed republicans in the fleets, it stands to reason that they did not hold much power in the relative calm of the Spithead mutiny or the fragmented chaos of the Nore, despite Thompson's claims.

The publication of Dugan's The Great Mutiny marked the last largescale examination of the 1797 mutinies. Many smaller works have since addressed gaps in the analysis of these key events and have involved varied approaches from different academic fields. One important recent effort, Richard Woodman's A Brief History of Mutiny (2005), is notable for a variety of reasons. It is one of the few general histories of naval mutiny that has ever been published, all the more impressive given that Woodman is not a professional historian. An author, amateur historian and naval aficionado, Woodman has published widely on the topic of the Royal Navy; his best-known work being The Sea Warriors which contextualized the historical fiction of authors such as C.S. Forester and Patrick O'Brien. ${ }^{40}$ In A Brief History of Mutiny, he covered nearly four hundred years of naval insurrection, from the days of Sir Francis Drake to the mutiny aboard USS Vance in the 1960s. He dedicated two full chapters to discussing the Spithead and Nore mutinies, and in doing so analyzed them in a relatively separate manner compared to previous authors.

Woodman's description of the causes of the mutiny at Spithead is perhaps one of the simplest that has been published on the topic. He acknowledged the potential role of "revolutionary zeal" in its outbreak, but, like Dugan, stated that it is all-but impossible to gauge "to what extent it was merely a subject of discussion among the fleet's messdecks and to

\footnotetext{
${ }^{37}$ Dugan, The Great Mutiny, 473.

${ }^{38}$ E.P. Thompson, The Making of the English Working Class (London: Penguin Books, 1963), 162, 183-4.

${ }^{39}$ Dugan, The Great Mutiny, 473.

${ }^{40}$ Richard Woodman, The Sea Warriors: Fighting Captains and Frigate Warfare in the Age of Nelson (New York: Carroll \& Graf Publishers, 2001).
} 
what extent it was a real motivator for change." 41 Regarding the central factors of the mutiny's outbreak, Woodman focused on five major grievances which the seamen themselves clearly articulated: issues of pay, leave, food, medical care, and punishment. Many officers at the time were quite sympathetic to at least some of these demands, and even Nelson acknowledged the Admiralty's failings in properly paying its sailors. One final, yet important, aspect of Spithead that Woodman highlighted was the cohesion of the mutinous fleet. The anchorage at Spithead gave the crews ample opportunity to organize en masse, and the mutiny erupted. However, as the Channel Fleet's cohesion gave rise to the mutiny, so too did it prevent its escalation, which Woodman referred to as the distinction between the mutineers' discipline and disobedience. ${ }^{42}$ The sailors at Spithead clearly maintained their discipline, despite their disobedience, but as will be seen, this was not the case a few weeks later at the Nore.

Although his chapter on the Nore was much shorter than that on the mutiny at Spithead, Woodman was still able to provide ample contextual information in addition to his analysis. He discussed the formation of the North Sea Squadron to counter the Dutch threat in the region and emphasized its eventual importance at Camperdown several months after the mutiny. Additionally, he made the crucial observation that the ships at the Nore did not constitute a "fleet" in their own right. ${ }^{43}$ The ships were transitory, not belonging to a single squadron or unified command structure, and it was this factor that led to the violence at the Nore and the mutiny's ultimate failure. This, Woodman argued, was the key difference between the mutinies at Spithead and the Nore, not some overblown emphasis on Jacobinism or revolutionary fervour. Such radical ideas, of course, might have existed at either affair, but the central difference between the seamen's success at Spithead and failure at the Nore came down to the cohesion of the mutineers and their ability to maintain internal discipline while simultaneously expressing their discontent through disobedience.

Woodman was the first to describe the causes of the Spithead and Nore mutinies in such simple terms. However, the first decade of the twenty-first century also saw a flurry of articles that clearly displayed that the debate over the causes of mutiny was still very much alive. As with Woodman's book, a great number of these articles present the Great

\footnotetext{
${ }^{41}$ Richard Woodman, A Brief History of Mutiny (London: Constable \& Robinson Ltd., 2005), 97.

${ }^{42}$ Woodman, A Brief History of Mutiny, 105

${ }^{43}$ Woodman, A Brief History of Mutiny, 114.
} 
Mutinies as one example of many, one of the few exceptions being Anthony Brown's The Nore Mutiny - Sedition or Ships' Biscuits? (2006). Looking exclusively at the Nore, Brown came to a very similar conclusion to Woodman, arguing that the lack of cohesion at the Nore precluded the success of the mutiny and the possibility of any organized revolutionary organization from seizing control. Failures of communication at the Nore both prevented its success, and were responsible for its outbreak, which may well have been averted had news of the end of the Spithead mutiny arrived earlier. ${ }^{44}$

Historian, Niklas Frykman also drew attention to communication in his 2010 analysis of the mutiny on the frigate Hermione. Although he did not explicitly discuss the Spithead and Nore mutinies in any great depth in this article, Frykman provided clear insight into his understanding of the causes of naval mutinies, one quite different from that of Woodman or Brown. He did not completely discount the role that the grievances of the seamen played in the outbreak of mutiny on the Hermione. Rather, he argued more explicitly for the effects of the "cosmopolitan networks of the revolutionary Atlantic" as a cause for mutiny, in addition to dispelling the "great man myth" that surrounds the discussion of insurrection at sea. ${ }^{45}$

One of the central factors to Frykman's argument was his belief that mutiny could not be fully understood in isolation, and to study each mutiny as an individual event would prevent proper analysis of systematic issues at work. ${ }^{46}$ While this was not a new argument, certain mutinies, including those of Spithead and the Nore, were traditionally seen to exist outside of this rule. Whether due to their size, scope, or outcome, these events were seen as unique among the wider analysis of the subject, as was quite clear in most analyses up to this point. Frykman disagreed, however, and drew parallels between the revolutionary tendencies scholars such as E.P. Thompson saw at Spithead and the Nore and smaller but, as he argued, no less isolated mutinies, such as the Hermione. In Frykman's eyes, the flurry of mutinies in the late eighteenth century were primarily rooted in the ideals of the French Revolution and the Rights of Man, not in questions of pay or leave.

In his analysis of the Hermione mutiny, Frykman decried previous efforts for succumbing to what he termed "a miniature version of the great man theory of history." ${ }^{47} \mathrm{He}$ argued that by putting so much emphasis on

\footnotetext{
${ }^{44}$ Brown, "The Nore Mutiny - Sedition or Ships' Biscuits? A Reappraisal," 62.

${ }^{45}$ Frykman, "The Mutiny on the Hermione," 177.

${ }^{46}$ Frykman, "The Mutiny on the Hermione," 160.

${ }^{47}$ Frykman, "The Mutiny on the Hermione," 159.
} 
The Graduate History Review 9, no. 1 (2020)

the action or inaction of the individual(s) in charge of the specific circumstances, it became nigh-impossible to draw the sort of far-reaching analysis he was attempting. At its heart, Frykman's argument was not incorrect, as many naval historians have tended to describe mutinies as a battle of wills between the officers and ringleaders, such as between Fletcher Christian and Captain Bligh of Bounty fame, or the crew and Captain Hugh Pigot of the Hermione. While this may well have been true for the sources about which Frykman was writing, in recent years the discussion surrounding the causes of mutiny has taken a distinct turn towards the collective, away from the focus on individuals, and even historians themselves.

Recently, the debate over the causes of naval mutiny has, at least in part, left the historian's realm for analysis by sociologists, as the study of mutiny as a form of collective action has led scholars to problematize the narrative of grievances that was passed down since the days of William Neale's original book. In 2016, Michael Hechter, Steven Pfaff, and Patrick Underwood (henceforth Hechter et al.), a trio of sociologists at Arizona State University and the University of Washington published an article where they attempted to analyze grievances as the central cause for mutiny in the Royal Navy over the course of a century. ${ }^{48}$ As this paper was published by sociologists, it unfortunately does not provide the same level of historical context to its topic, nor does it fully engage with the previous historical literature regarding the study of mutiny in the Royal Navy. However, despite potential flaws with the predictive claims of their model, Hechter et al. still managed to provide a fascinating analysis on the role of grievances in the outbreak of mutiny in one of the most convincing arguments on the topic yet published .

In their article, Hechter et al. chose to focus on two specific types of grievances: structural and incidental. Structural grievances are chronic, existing due to some inequality in the social structure. For sailors in the Royal Navy these would have consisted of issues of pay, leave, and difficult working conditions, among many others. While these factors would by no means have been viewed favourably by the sailors, they were deemed to be "their lot in life," and Hechter et al. argued that these types of grievances did not usually lead crews to mutiny. On the other hand, incidental grievances "arise from wholly unanticipated situations that put

\footnotetext{
${ }^{48}$ Michael Hechter, Steven Pfaff, and Patrick Underwood, "Grievances and the Genesis of Rebellion: Mutiny in the Royal Navy, 1740-1820," American Sociological Review 81, no. 1 (2016): 165.
} 
groups at risk." 49 For the eighteenth-century navy, these would have included issues such as excessive punishment, disease, and incompetent officers, issues that were much more likely to threaten the survival of the ships' company as a whole. ${ }^{50}$ Despite issues with the sociological modeling they used in their analysis, Hechter et al. still managed to argue quite effectively that mutiny was much more likely when incidental and structural grievances coincided. In effect, this answered the major issue that Conrad Gill raised over a century earlier, of how grievances that had existed for decades or longer could play a role in such a sudden breakdown of order and discipline.

Hechter et al. explicitly chose to ignore the Spithead and Nore mutinies in their study as "those cases were not independent," but have since dedicated a separate article to analyzing the Nore mutiny in particular. In "The Problem of Solidarity in Insurgent Collective Action" (2016), Hechter et al. use the Nore mutiny as a case study to question the cohesiveness of insurgent groups. ${ }^{51}$ Although less relevant to the discussion of the mutiny's causes than their previous article, Hechter et al. agreed with Woodman that it was the lack of collective solidarity between the ships at the Nore that led to the mutiny's eventual failure. The ringleaders emphasized an "all or nothing" approach to their demands to compel obedience from their shipmates, using illegal oathtaking and other actions to enforce loyalty, but their efforts proved less than successful. ${ }^{52}$ Ultimately the risks undertaken by the Nore mutineers were see as too great by the sailors, especially in the face of the benefits won at Spithead mere months earlier, and the mutiny collapsed.

Despite the fairly limited addition to our understanding of the causes of the Spithead and Nore Mutinies, much of what Hechter et al. argued in their first article is still relevant to the wider historical discussion. ${ }^{53}$ Their very argument for choosing to ignore the Great Mutinies directly conflicted with Frykman's belief that mutinies cannot be studied in isolation, suggesting that Frykman's argument was not taken for granted within the field. This also questioned Frykman's own criticism of the "great man myth," as the presence or absence of incidental grievances often came down to the action or inaction of a single person, usually the

\footnotetext{
${ }^{49}$ Hechter et al, "Grievances and the Genesis of Rebellion," 167.

${ }^{50}$ Hechter et al, "Grievances and the Genesis of Rebellion," 168.

${ }^{51}$ Michael Hechter, Steven Pfaff, and Katie Corcoran, "The Problem of Solidarity in Insurgent Collective Action: The Nore Mutiny of 1797," Social Science History 40, no. 2 (2016): 247.

${ }^{52}$ Hechter et al, "The Problem of Solidarity in Insurgent Collective Action," 267.

${ }^{53}$ Hechter et al, "Grievances and the Genesis of Rebellion," 175.
} 
commanding officer. Additionally, Hechter et al. explicitly questioned the role that revolutionary ideas played in the outbreak of mutiny, suggesting that the factors that Frykman and others argued were not generally the defining features that led one crew to mutiny when another did not. ${ }^{54}$

The study of mutiny in the Royal Navy is as old as the events themselves, since contemporaries were as interested as modern historians by the question of what could lead to such systematic loss of order and discipline. The example of the Great Mutinies of 1797 makes clear that many analyses are unique to their authors and the times in which they were written. However, certain themes have remained constant from the work of William Johnson Neale in the 1840s to the present. The more controversial of these themes is the "sedition" highlighted in Brown's article, emphasized in some works as "revolutionary fervor." It is not possible to completely discount such suggestions, as there is at least some evidence that such ideas influenced actors at Spithead and the Nore. Nevertheless, historians must be careful to avoid drawing too much importance to this factor, as it is clearly easy to give it too much credence despite such scant evidence.

Most important, however, is the discussion surrounding the grievances of the seamen of the Royal Navy. Few scholars have denied the central role such factors played in the outbreak of mutiny in 1797, and the discussion itself has developed significantly since the work of William Johnson Neale. Debate has existed surrounding the relative importance of individual grievances, but it was not until recently that the very concept of grievances themselves was properly questioned. The work of Michael Hechter, Steven Pfaff, and Patrick Underwood challenged the findings of a century of historians and provided a better understanding of how individual grievances did or did not affect mutiny in the Royal Navy. Even with this new knowledge, the discussion regarding the exact role grievances played in the Great Mutinies is a subject that still needs to be fully explored, and the collection of essays published by Ann Coats and Philip MacDougall in 2011 will greatly assist. ${ }^{55}$ However, it is quite clear that despite the need for additional research to further our understanding of the events of 1797, the age-old question of "sedition or ships' biscuits" is one that has long been answered.

\footnotetext{
${ }^{54}$ Hechter et al, "Grievances and the Genesis of Rebellion," 183.

${ }^{55}$ Ann Coats and Philip MacDougall (ed.), The Naval Mutinies of 1797: Unity and Perseverance (Boydell, 2011).
} 


\section{Bibliography}

Brown, Anthony. "The Nore Mutiny - Sedition or Ships' Biscuits? A Reappraisal." The Mariner's Mirror 91 no. 1 (2006): 60-74.

Coats, Ann, and Philip MacDougall, eds. The Naval Mutinies of 1797: Unity and Perseverance. Boydell, 2011.

Dugan, James. The Great Mutiny. London: The Trinity Press, 1965.

Frykman, Niklas. "The Mutiny on the Hermione: Warfare, Revolution, and Treason in the Royal Navy." Journal of Social History 44 no. 1 (2010): 159-187.

Gill, Conrad. The Naval Mutinies of 1797. University of Manchester Press, 1913.

Goodwin, Gordon. 2015 "Neale, William Johnstoune Nelson (18121893), lawyer and novelist." Oxford Dictionary of National Biography. 20 March 2019: https://doi.org/10.1093/ref:odnb/19833.

Hannay, David. Naval Courts Martial. University of Cambridge Press, 1914.

Hechter, Michael, Steven Pfaff, and Patrick Underwood. "Grievances and the Genesis of Rebellion: Mutiny in the Royal Navy, 17401820." American Sociological Review 81 no. 1 (2016): 165-189.

Hechter, Michael, Steven Pfaff, and Katie Corcoran. "The Problem of Solidarity in Insurgent Collective Action: The Nore Mutiny of 1797." Social Science History 40 no. 2 (2016): 247-270.

Keegan, John. The Face of Battle. Jonathan Cape, 1976.

Lambert, Andrew. Review of The Naval Mutinies of 1797: Unity and Perseverance edited by Ann Coats and Philip MacDougall, Annual Bulletin of Historical Literature 96 no. 1 (2013): 89-90.

Manwaring, George and Bonamy Dobrée. The Floating Republic. London: Geoffrey Bles, 1935.

Neale, William Johnson. History of the Mutiny at Spithead and the Nore: With an Enquiry into its Origin and Treatment, and Suggestions for the Prevention of Future Discontent in the Royal Navy. London: Bradburn and Evans, 1842.

Thompson, E.P. The Making of the English Working Class. London: Penguin Books, 1963.

Woodman, Richard. A Brief History of Mutiny. London: Constable \& Robinson Ltd., 2005.

Woodman, Richard. The Sea Warriors: Fighting Captains and Frigate Warfare in the Age of Nelson. New York: Carroll \& Graf Publishers, 2001. 